\title{
A Rare Presentation of Poorly Differentiated Lung Carcinoma with Duodenal Metastasis and Literature Review
}

\author{
Ahmed Ahmed ${ }^{a} \quad$ Umair M. Nasir ${ }^{a} \quad$ Paul Delle Donna ${ }^{a} \quad$ Vanessa Swantic $^{a}$ \\ Shahida Ahmed ${ }^{\text {b }}$ Christopher Lenza ${ }^{c}$ \\ aDivision of Medicine, Rutgers New Jersey Medical School, Newark, NJ, USA; ${ }^{b}$ Division of \\ Pathology, East Orange Department of Veteran's Affair, East Orange, NJ, USA; \\ 'Gastroenterology and Hepatology, East Orange Department of Veteran's Affair, \\ East Orange, NJ, USA
}

\section{Keywords}

Duodenum · Gastrointestinal bleeding · Immunohistochemistry ·

Esophagogastroduodenoscopy

\begin{abstract}
Lung cancer is a common malignancy which is frequently found to metastasize to distant sites including bone, liver, and adrenal glands. There are rare reports of metastases to the gastrointestinal $(\mathrm{Gl})$ tract, with the duodenum being the most uncommon. We present a rare case of a poorly differentiated lung carcinoma metastasizing to the duodenum. This case enhances the medical literature as it provides additional distinct features to the clinical and histological presentation of metastatic lung carcinoma to the GI tract. A 61-year-old male with a history of poorly differentiated lung carcinoma presented with worsening dizziness, fatigue, and early satiety. He had extensive workup done in the past for hemoptysis including a computerized tomography scan of the chest which showed a new lobulated, apical lesion and hilar
\end{abstract}




\section{Case Reports in Gastroenterology}

Case Rep Gastroenterol 2020;14:186-196

Ahmed et al.: Poorly Differentiated Lung Carcinoma Metastasis to the Duodenum

lymphadenopathy. He ultimately had a transthoracic fine-needle aspiration (FNA) of the mass and was later diagnosed with poorly differentiated lung carcinoma. On examination, the patient was noted to be pale, tachycardic, and hypotensive. The patient was noted to have an acute drop in his hemoglobin requiring fluid resuscitation, multiple blood transfusions, and evaluation with an esophagogastroduodenoscopy. He was found to have an oozing ulcer in the third portion of the duodenum whose biopsies showed poorly differentiated carcinoma with areas of neuroendocrine differentiation, similar to his lung biopsy results, which was consistent with metastatic lung carcinoma.

\section{Introduction}

Lung cancer is a common malignancy which is frequently found to metastasize to distant sites. The most common location of these metastases are to bone, liver, and adrenal glands. There are reports of metastases to the gastrointestinal (GI) tract; however, it is uncommon [1, 2]. When lung cancer does metastasize to the GI tract, it is usually found in the jejunum, followed by the ileum, with the duodenum being a rare location [1]. In addition to endoscopic examination, immunohistochemical (IHC) staining and histological analysis are key to the diagnosis, as it is often necessary to differentiate between different carcinomas or to distinguish a primary tumor from a metastatic tumor. We present the case of a 61-year-old male with a history of poorly differentiated lung carcinoma, who was found to have a duodenal mass on esophagogastroduodenoscopy (EGD) diagnosed as metastatic poorly differentiated lung carcinoma after histological analysis.

\section{Case Presentation}

A 61-year-old male with a past medical history of chronic obstructive pulmonary disease, lung cancer, and peptic ulcer disease presented with 1 month of worsening dizziness, fatigue, and early satiety. He stated that his dizziness occurred more with changes in position and he was having increasing limitations with his routine activities such as cooking and performing small house chores. He reported decreased exercise tolerance as he noticed he had shortness of breath after walking 1-2 blocks, which decreased from his baseline of above 5 blocks. He also reported palpitations but denied leg swelling, worsening cough, or orthopnea. During this time period, he also reported nausea, decreased appetite, and nonspecific, dull, non-radiating abdominal pain, especially after eating. He denied any hematochezia but admitted to occasional dark-colored stools. He denied any diarrhea, constipation, or use of pain medications, including over-the-counter nonsteroidal anti-inflammatory drugs. He was using a proton pump inhibitor, but stated it provided little relief. He denied any family history of malignancies but admitted to a 20-pack year history of smoking.

On admission, the patient was afebrile, tachycardic with a heart rate of 115 , and had a blood pressure of 92/60. His examination was notable for skin pallor, dry mucous membranes, and a cachectic appearance. Labs were significant for a hemoglobin (Hb) of $7.2 \mathrm{~g} / \mathrm{dL}$ (baseline being around 12-13), a mildly elevated blood urea nitrogen of $27 \mathrm{mg} / \mathrm{dL}$, albumin 


\section{Case Reports in Gastroenterology}

Case Rep Gastroenterol 2020;14:186-196

(c) 2020 The Author(s). Published by S. Karger AG, Basel www.karger.com/crg

of $3.1 \mathrm{~g} / \mathrm{dL}$, and normal prothrombin time, partial thromboplastin time, international normalized ratio, bilirubin, and lactate.

Of note, the patient was recently diagnosed with lung cancer 6 months prior to his presentation. At that time, he was complaining of chronic hemoptysis, unintentional 15-pound weight loss, and worsening fatigue over a 6 -month time period. Prior chest X-rays were negative; however, a computerized tomography (CT) scan of the chest showed a new left-sided lobulated, apical lesion measuring $4 \times 2 \mathrm{~cm}$ with bronchial involvement, and hilar lymphadenopathy (Fig. 1). The patient was worked up for an infectious source, including tuberculosis, which ended up being negative. He had a bronchoscopy with bronchoalveolar lavage and a transbronchial biopsy done, which showed inflammatory cells but was negative for any malignant cells on brushing or washing. However, due to a high suspicion for malignancy, the patient ultimately had a transthoracic fine-needle aspiration (FNA) of the mass. The final pathology results demonstrated poorly differentiated carcinoma that was weakly positive (only a few scattered cells) for CK-7, synaptophysin, and calretinin on IHC staining (Fig. 2). IHC staining of the specimen was also negative for CK-20, p63, TTF-1, chromogranin, melan-A, CDX-2, PSA, and PSMA (Fig. 2). The patient was further worked up for his malignancy with a magnetic resonance imaging scan of the brain which was negative for any lesions. However, a positron emission tomography scan was done and found an active left upper-lobe apical mass as well as hypermetabolic mediastinal and hilar lymphadenopathy , which were compatible with metastatic disease. His pretreatment stage at the time was determined to be T4N2M0, stage IIIB. He was started on a paclitaxel/carboplatin chemotherapy regimen with concurrent radiation therapy (total of 6,000 cgy) and was in the process of planning a surgical resection evaluation of the lung tumor prior to his hospitalization.

The patient was stabilized with fluid resuscitation and received 2 initial units of packed red blood cells. An EGD was done and showed an ulcer in the third portion of the duodenum with heaped-up borders and evidence of oozing (Fig. 3). Bipolar cautery was performed, and biopsies were obtained which showed poorly differentiated carcinoma histologically (Fig. 2). IHC staining of the duodenal mass was negative for CK-20, p63, P-40, Napsin-A, CDX-2, TTF-1, chromogranin, calretinin, CD-20, CD-3, SOX-10, and melan-A (Fig. 2). The patient's Hb continued to drop post cauterization, and he required multiple additional transfusions. He was deemed a poor surgical candidate due to his comorbidities and metastatic disease and eventually had a palliative gastroduodenal artery embolization. After embolization, the patient's $\mathrm{Hb}$ stabilized, and he was ultimately discharged after monitoring his hemodynamics, with close outpatient follow-up for further care as he wanted to continue to pursue medical therapies.

\section{Discussion}

Lung cancer most often metastasizes to the bones, liver, and adrenal glands; metastasis to the GI system is rare with studies showing a frequency of only $0.2-1.7 \%[1,2]$. Other autopsy studies demonstrated a slightly higher prevalence of $4.7-14 \%[3,4]$. In support of the rarity, a report by Oda et al. [5] on the primary foci of gastric metastases from various cancers found lung cancer to be $6.8 \%$ (84/1,235 cases), breast cancer $11.6 \%$ (61/526 cases), esophageal cancer $11.5 \%$ (49/427 cases), and malignant melanoma 29.6\% (21/71 cases). Lung 


\section{Case Reports in Gastroenterology}

Case Rep Gastroenterol 2020;14:186-196

DOI: $10.1159 / 000506927$

(c) 2020 The Author(s). Published by S. Karger AG, Basel www.karger.com/crg

Ahmed et al.: Poorly Differentiated Lung Carcinoma Metastasis to the Duodenum

cancer metastases to the GI tract are primarily found in advanced disease stages. In 64 documented cases, the most common site of primary lung metastasis to the GI tract was the jejunum (50.9\%), followed by the ileum (33.3\%), with the duodenum being relatively uncommon (15.8\%) [1]. Although any tumor cell types of lung cancer can develop GI metastases, the most common type to metastasize is squamous cell, followed by large cell, and then adenocarcinoma [6].

The symptoms of metastasis to the GI tract are nonspecific, making early diagnosis difficult. Generally, the most common symptoms of metastasis to the GI tract are abdominal pain, cramping, nausea, vomiting, weight loss, and constipation [7-9]. Moreover, complications of these metastases often include GI perforation, obstruction, and hemorrhage, whereas complications such as pneumoperitoneum and intussusception are relatively uncommon $[5,10]$. Total-body imaging used during lung cancer staging may increase the discovery of GI masses [11]. However, adding to the diagnostic challenge, imaging studies, such as a CT scan of the abdomen, generally have a low sensitivity for detecting GI metastases [12]. When discovered on CT imaging, GI metastases have been visualized as either wall thickening, an exophytic mass, or an intraluminal polypoid mass [13].

IHC staining and histological analysis are crucial for cancer diagnosis as it is often necessary to differentiate between different carcinomas or to distinguish a primary tumor from a metastatic tumor. In general, adenocarcinoma can be diagnosed with morphological findings of acinar/tubular structures or mucin production as well as IHC-positive markers for TTF-1 and/or Napsin-A. Squamous cell carcinoma (SCC) is usually defined by keratinization or intercellular bridges with associated IHC markers such as P-40, P-63, and CK-5/CK-6, with P-40 being the most sensitive and specific [14]. Neuroendocrine tumors are usually categorized into 3 subtypes: small cell lung carcinoma, large cell neuroendocrine carcinoma, and carcinoid tumor. All subtypes share features of neuroendocrine differentiation with IHC expression of at least one neuroendocrine marker including chromogranin A, synaptophysin, or CD-56 [14]. Moreover, levels of CK-7, CK-20, and TTF-1 have been used to distinguish pulmonary and GI carcinomas [15]. Lung adenocarcinomas often have the TTF-1 (+)/CK-7 (+)/CK-20 (-) immunoprofile, whereas GI adenocarcinomas usually have the TTF-1 (-)/CK-7 (-)/CK-20 (+) profile [16]. In one study, CK-7 and TTF-1 were found to be co-expressed in lung adenocarcinomas, even those that were poorly differentiated [2]. To help differentiate between primary lung and GI tumors, IHC staining for CDX-2 is often utilized as it is frequently expressed in primary intestinal adenocarcinomas; thus, negative staining of an intestinal lesion for CDX-2 with positive CK-20 staining often indicates a metastasis from a non-GI tumor [2].

Literature review, to the best of our knowledge, focusing specifically on duodenal metastasis of lung cancer, demonstrated only 16 cases. Based on those case reports, 7 cases (44\%) were adenocarcinoma, 5 cases (31\%) SCC, and $2(12.5 \%)$ cases of both large and small cell carcinoma (Table 1). For the present case, the pathology results of the FNA showed sheets of atypical cells with focal necrosis, and prominent nucleoli being dispersed without a specific pattern, consistent with a diagnosis of poorly differentiated carcinoma with focal neuroendocrine differentiation (Fig. 2). IHC staining of the lung mass was negative for CK-20, p63, TTF1 , chromogranin, and melan-A which was immunohistochemically identical to the duodenal mass biopsy, which also showed poorly differentiated carcinoma histologically (Fig. 2). The IHC profile of both biopsies could not pinpoint a specific type of carcinoma, and histological 
analysis only showed areas of focal neuroendocrine differentiation; highlighting the unique aspect of this case.

The exact mechanism of GI metastasis from a primary lung cancer is still being established; yet, it has been hypothesized that it occurs through hematogenous spread via the spiral veins or lymphogenous spread from the mediastinum to the retroperitoneum and mesentery. Other theories revolve around direct invasion of tumor cells or intraperitoneal dissemination $[17,18]$. Moreover, several hypotheses on the origin of SCC in the duodenum have been suggested, including isolated ectopic squamous cells, transformation of basal cells into squamous cells, chronic mucosal insults leading to squamous metaplasia, and multipotent stem cells in the GI mucosa [10, 17-19].

In cases of high clinical suspicion, especially in uninvestigated anemia or melena, endoscopic evaluation and biopsy is highly recommended. On endoscopy, most metastatic lesions present as "volcano-like tumors" or submucosal tumors with bridging folds and superficial ulcerations [20,21]. Moreover, capsule endoscopy has been shown to be more effective in detecting small bowel abnormalities when compared to push enteroscopy and is usually indicated for cases of obscure GI bleeds [22]. The literature also has evidence of technetium-labelled red blood cell scans being used to successfully locate the source of bleeding from a primary lung cancer metastasis to the small bowel [10]. In this case, the patient presented with nonspecific symptoms including early satiety, vague abdominal pain, and melena. However, more specifically, he was noted to have a significant drop in his Hb levels compared to his baseline, with signs of hemodynamic abnormalities which prompted an urgent EGD. His EGD showed an ulcerative mass in the third portion of the duodenum with heaped-up borders and evidence of bleeding.

The treatment of duodenal metastasis tends to be challenging, and it depends on variables including the site of the duodenal involvement, patient characteristics, and size of the lesions. Endoscopic resection of smaller duodenal metastatic lesions $(\leq 1 \mathrm{~cm})$ has been shown to be safe and effective, especially in cases where complete resection is obtainable solely by endoscopic methods [23]. Surgical treatment of duodenal metastases has not been shown to increase survival but is often pursued for palliative relief [24,25]. Surgical treatment often consists of a duodenectomy or pancreaticoduodenectomy (Whipple procedure) [26]. Unfortunately, GI metastasis from lung cancer usually indicates a very poor prognosis [24, 25]. The mean survival time after discovery of GI metastasis ranges from 2 to 4 months according to Morris and Deitsch [27] and Wiedemer [28], respectively. In this case, surgical treatment was not recommended due to the patient's comorbidities and metastatic disease; a palliative gastroduodenal artery embolization was ultimately performed with good response.

\section{Acknowledgement}

The authors would like to thank the Division of Medicine at Rutgers NJMS for their assistance in the development of the drafts and final manuscript. 


\section{Case Reports in Gastroenterology}

Case Rep Gastroenterol 2020;14:186-196

DOI: $10.1159 / 000506927$

(C) 2020 The Author(s). Published by S. Karger AG, Base www.karger.com/crg

Ahmed et al.: Poorly Differentiated Lung Carcinoma Metastasis to the Duodenum

\section{Statement of Ethics}

The subject in this case report has given their informed consent to publish their case, including publication of images. This report did not need IRB approval based on Department of Health and Human Services criteria.

\section{Disclosure Statement}

The authors have no conflicts of interest to declare.

\section{Funding Sources}

The authors confirm that they have no funding sources to disclose.

\section{Author Contributions}

Ahmed Ahmed contributed to the conception, literature review, drafting, and revision of the article. Umair Nasir contributed to the revision of the article. Paul Delle Donna contributed to the revision of the article. Vanessa Swantic contributed through literature review and drafting of the article. Shahida Ahmed contributed figures, figure explanations, and revision of the article. Christopher Lenza contributed to the drafting and revision of the article.

\section{References}

1 Yang CJ, Hwang JJ, Kang WY, Chong IW, Wang TH, Sheu CC, et al. Gastro-intestinal metastasis of primary lung carcinoma: clinical presentations and outcome. Lung Cancer. 2006 Dec;54(3):319-23.

2 Rossi G, Marchioni A, Romagnani E, Bertolini F, Longo L, Cavazza A, et al. Primary lung cancer presenting with gastrointestinal tract involvement: clinicopathologic and immunohistochemical features in a series of 18 consecutive cases. J Thorac Oncol. 2007 Feb;2(2):115-20.

3 Yoshimoto A, Kasahara K, Kawashima A. Gastrointestinal metastases from primary lung cancer. Eur J Cancer. 2006 Dec;42(18):3157-60.

4 Antler AS, Ough Y, Pitchumoni CS, Davidian M, Thelmo W. Gastrointestinal metastases from malignant tumors of the lung. Cancer. 1982 Jan;49(1):170-2.

5 Oda I, Kondo H, Yamao T, Saito D, Ono H, Gotoda T, et al. Metastatic tumors to the stomach: analysis of 54 patients diagnosed at endoscopy and 347 autopsy cases. Endoscopy. 2001 Jun;33(6):507-10.

6 Hillenbrand A, Sträter J, Henne-Bruns D. Frequency, symptoms and outcome of intestinal metastases of bronchopulmonary cancer. Case report and review of the literature. Int Semin Surg Oncol. 2005 Jun;2(1):13.

7 Sanli Y, Adalet I, Turkmen C, Kapran Y, Tamam M, Cantez S. Small bowel metastases from primary carcinoma of the lung: presenting with gastrointestinal hemorrhage. Ann Nucl Med. 2005 Apr;19(2):161-3.

8 Kadakia SC, Parker A, Canales L. Metastatic tumors to the upper gastrointestinal tract: endoscopic experience. Am J Gastroenterol. 1992 Oct;87(10):1418-23.

9 Hsu CC, Chen JJ, Changchien CS. Endoscopic features of metastatic tumors in the upper gastrointestinal tract. Endoscopy. 1996 Feb;28(2):249-53.

10 Memon Z, Ferm S, Fisher C, Hassam A, Luo J, Kim SH. Rare Case of Duodenal Metastasis From Pulmonary Squamous Cell Carcinoma. J Investig Med High Impact Case Rep. 2017 Oct;5(4):2324709617737567. 
11 Usmanij EA, de Geus-Oei LF, Bussink J, Oyen WJ. Update on F-18-fluoro-deoxy-glucose-PET/computed tomography in nonsmall cell lung cancer. Curr Opin Pulm Med. 2015 Jul;21(4):314-21.

12 Linsen PV, Linsen VM, Buunk G, Arnold DE, Aerts JG. Iron deficiency anemia as initial presentation of a nonsmall cell lung carcinoma: A case report. Respir Med Case Rep. 2015 Sep;16:109-11.

13 Liu W, Zhou W, Qi WL, Ma YD, Xu YY. Gastrointestinal hemorrhage due to ileal metastasis from primary lung cancer. World J Gastroenterol. 2015 Mar;21(11):3435-40.

14 Inamura K. Update on Immunohistochemistry for the Diagnosis of Lung Cancer. Cancers (Basel). 2018 Mar;10(3):72.

15 Al-Zahrani IH. The value of immunohistochemical expression of TTF-1, CK7 and CK20 in the diagnosis of primary and secondary lung carcinomas. Saudi Med J. 2008 Jul;29(7):957-61.

16 Su YC, Hsu YC, Chai CY. Role of TTF-1, CK20, and CK7 immunohistochemistry for diagnosis of primary and secondary lung adenocarcinoma. Kaohsiung J Med Sci. 2006 Jan;22(1):14-9.

17 Cheng G. A case of lung squamous cell carcinoma with duodenal metastasis on FDG PET/CT. Clin Nucl Med. 2016 Aug;41(8):659-60.

18 Yamada H, Akahane T, Horiuchi A, Shimada R, Shibuya H, Hayama T, et al. A case of lung squamous cell carcinoma with metastases to the duodenum and small intestine. Int Surg. 2011 Apr-Jun;96(2):176-81.

$19 \mathrm{Hu}$ JB, Zhu YH, Jin M, Sun XN. Gastric and duodenal squamous cell carcinoma: metastatic or primary? World J Surg Oncol. 2013 Aug;11(1):204.

20 Ozdilekcan C, Songür N, Memiş L, Bozdoğan N, Köksal AS, Ok U. Lung cancer associated with a single simultaneous solitary metastatic lesion in stomach: a case report with the review of literature. Tuberk Toraks. 2010;58(1):78-84.

21 Kim HS, Jang WI, Hong HS, Lee CI, Lee DK, Yong SJ, et al. Metastatic involvement of the stomach secondary to lung carcinoma. J Korean Med Sci. 1993 Feb;8(1):24-9.

22 AlSaeed EF, Tunio MA, AlSayari K, AlDandan S, Riaz K. Duodenal metastasis from lung adenocarcinoma: A rare cause of melena. Int J Surg Case Rep. 2015;13:91-4.

23 Kamiyoshihara M, Otaki A, Nameki T, Kawashima 0, Otani Y, Morishita Y. [Duodenal metastasis from squamous cell carcinoma of the lung; report of a case]. Kyobu Geka. 2004 Feb;57(2):151-3.

24 Berger A, Cellier C, Daniel C, Kron C, Riquet M, Barbier JP, et al. Small bowel metastases from primary carcinoma of the lung: clinical findings and outcome. Am J Gastroenterol. 1999 Jul;94(7):1884-7.

25 Goh BK, Yeo AW, Koong HN, Ooi LL, Wong WK. Laparotomy for acute complications of gastrointestinal metastases from lung cancer: is it a worthwhile or futile effort? Surg Today. 2007;37(5):370-4.

26 Uehara K, Iijima K, Hasegawa S, Suda A, Nakazato Y. The metastasis to the digestive system from the primary lung cancer: a review of 1775 autopsies (in Japanese with English abstract). Geka (Surgery). 1979;41:13647.

27 Morris DM, Deitch EA. Clinically significant intestinal metastasis from a primary bronchogenic carcinoma. J Surg Oncol. 1983 Jun;23(2):93-4.

28 Wiedemer H, Godbole M, Appavu SK. Small bowel metastases in bronchogenic carcinoma. IMJ Ill Med J. 1981 Oct;160(4):228-30.

29 Hirai S, Hamanaka Y, Mitsui N, Sato K, Chatani N. [Solitary metachnonous jejunum and duodenum metastasis after surgical resection of lung cancer]. Kyobu Geka. 2010 Feb;63(2):129-32.

30 Hinoshita E, Nakahashi H, Wakasugi K, Kaneko S, Hamatake M, Sugimachi K. Duodenal metastasis from large cell carcinoma of the lung: report of a case. Surg Today. 1999;29(8):799-802.

31 Kostakou C, Khaldi L, Flossos A, Kapsoritakis AN, Potamianos SP. Melena: a rare complication of duodenal metastases from primary carcinoma of the lung. World J Gastroenterol. 2007 Feb;13(8):1282-5.

32 Steinhart AH, Cohen LB, Hegele R, Saibil FG. Upper gastrointestinal bleeding due to superior mesenteric artery to duodenum fistula: rare complication of metastatic lung carcinoma. Am J Gastroenterol. 1991 Jun;86(6):771-4.

33 Cremon C, Barbara G, De Giorgio R, Salvioli B, Epifanio G, Gizzi G, et al. Upper gastrointestinal bleeding due to duodenal metastasis from primary lung carcinoma. Dig Liver Dis. 2002 Feb;34(2):141-3.

34 Misra SP, Dwivedi M, Misra V, Dharmani S, Gupta M. Duodenal metastases from squamous cell carcinoma of the lung: endoscopic management of bleeding and biliary and duodenal obstruction. Indian J Gastroenterol. 2004 Sep-Oct;23(5):185-6.

35 Ito Y, Suzuki M, Oyamada Y, Kou H, Takeshita K, Asano K, et al. [A case of relapsed small cell lung cancer recognized by simple metastasis to the duodenum]. Nihon Kokyuki Gakkai Zasshi. 2001 Jan;39(1):30-4.

36 Iwamuro M, Uetsuka H, Makihata K, Yamamoto K. Metastatic tumors in the duodenum: A report of two cases. J Cancer Res Ther. 2015 Jul-Sep;11(3):648.

37 Rivera NT, Katz H, Weisbaum G, Guarneri R, Bray N, Constanza-Guaqueta D. Solitary metastasis to the small bowel from primary adenocarcinoma of the lung. J Gastrointest Cancer. 2014 Dec;45(S1 Suppl 1):91-5. 


\section{Case Reports in Gastroenterology}

\begin{tabular}{l|l}
\hline Case Rep Gastroenterol 2020;14:186-196 \\
\hline DOI: 10.1159/000506927 & $\begin{array}{l}\text { @ 2020 The Author(s). Published by S. Karger AG, Basel } \\
\text { www.karger.com/crg }\end{array}$ \\
\hline
\end{tabular}

Ahmed et al.: Poorly Differentiated Lung Carcinoma Metastasis to the Duodenum

38 Jarmin R, Azman A, Rahim R, Kosai NR, Das S. A rare case of intussusception associated with metastasized small cell carcinoma of lung. Acta Med Iran. 2012;50(11):782-4.
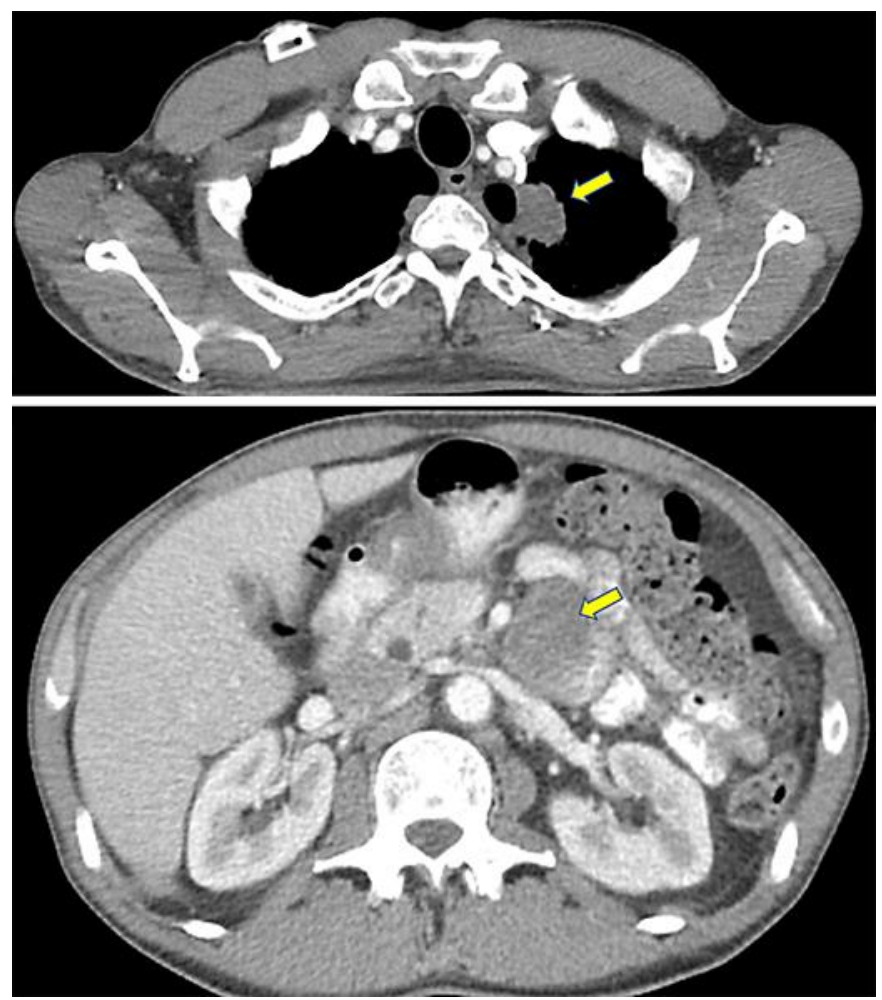

Fig. 1. A CT scan of the chest from the patient's prior hospitalization (top image) showing a large, lobulated, left apical lung mass (arrow). Transthoracic FNA results later came back positive for poorly differentiated lung carcinoma with focal neuroendocrine differentiation. The bottom image is from a CT scan of the abdomen that was done on presentation, which shows a large elliptical lesion (arrow) around the third portion of the duodenum, later found on esophagogastroduodenoscopy, whose biopsies were consistent with metastatic lung carcinoma. 


\section{Case Reports in Gastroenterology}
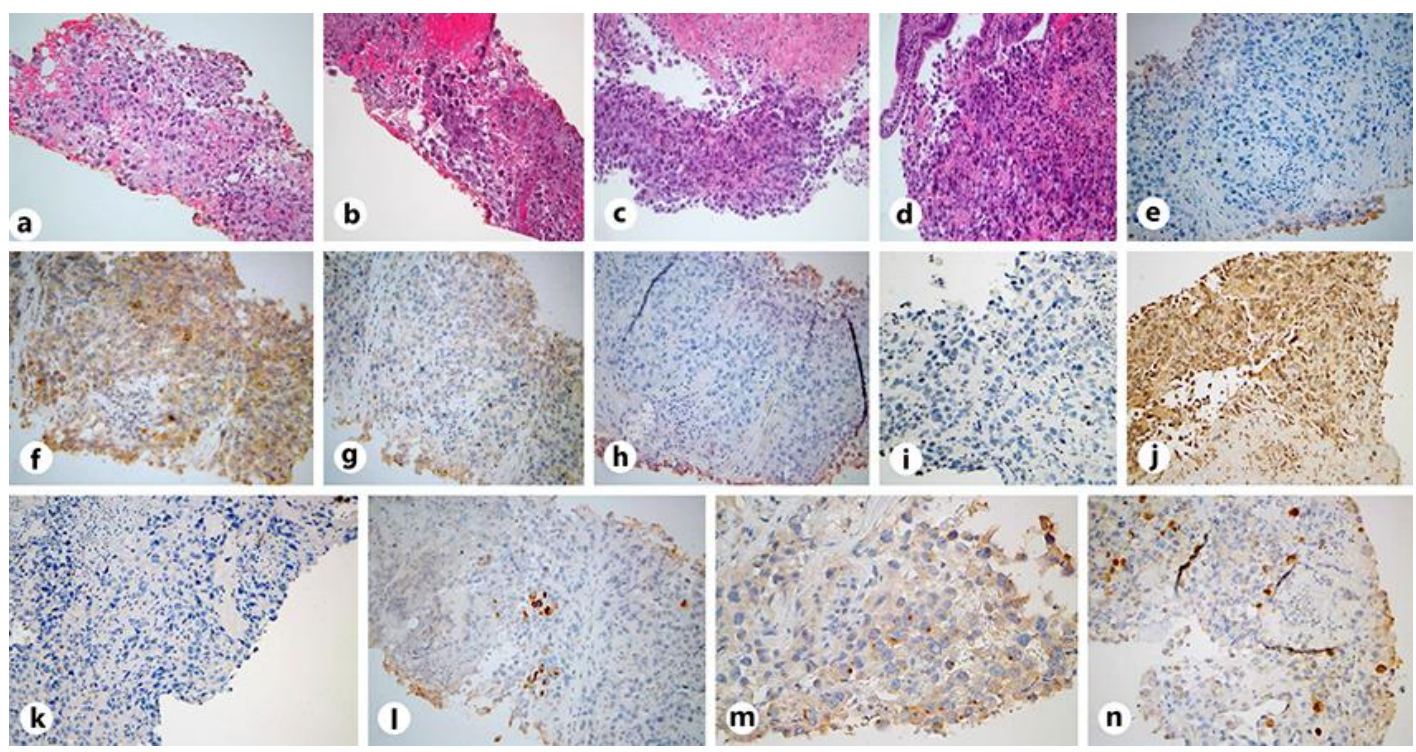

Fig. 2. a, b H\&E stain under $\times 20$ magnification demonstrating a poorly differentiated malignant neoplasm with focal neuroendocrine differentiation in the lung biopsy. c, d H\&E stain under $\times 20$ magnification demonstrating a poorly differentiated neoplasm in the duodenal mass biopsy. $\mathbf{e}-\mathbf{h}$ IHC stains $(\times 20)$ from the lung. e Negative CK-20 stain. $\mathbf{f}$ Negative P-63 stain. $\mathbf{g}$ Negative TTF-1 stain. $\mathbf{h}$ Negative chromogranin stain. i-I IHC stains from the duodenum $(\times 20)$. Identical to the lung samples, i shows a negative CK-20 stain, and $\mathbf{j}$ shows a negative TTF-1 stain. $\mathbf{k}$ Negative CDX-2 stain of the duodenal biopsy. Weakly positive lung biopsy stains $(\times 20)$ demonstrating CK-7 (I), synaptophysin $(\mathbf{m})$, and calretinin $(\mathbf{n})$. IHC staining of both biopsies were similar; however, ultimately the diagnosis was of undifferentiated histogenesis. 


\section{Case Reports in Gastroenterology}

DOI: $10.1159 / 000506927$

(c) 2020 The Author(s). Published by S. Karger AG, Basel www.karger.com/crg

Ahmed et al.: Poorly Differentiated Lung Carcinoma Metastasis to the Duodenum
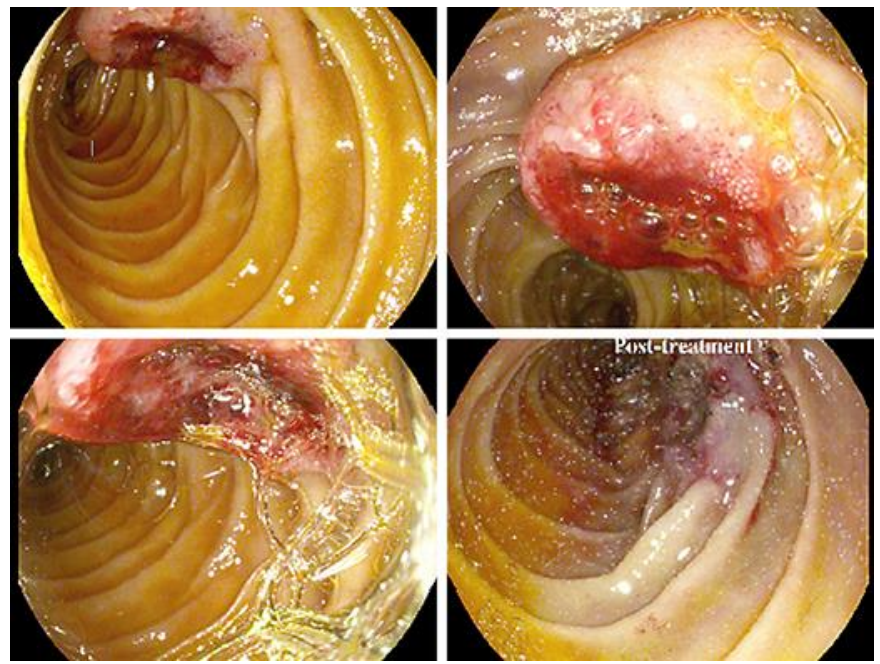

Fig. 3. Endoscopic images done during the patient's hospital course. The images demonstrate a large, oozing, edematous, heaped-up lesion with an ulcerated center in the third portion of the duodenum. The bottom right image was taken after an endoscopic bipolar electrocautery procedure. Biopsies from the lesion demonstrated metastatic disease histologically similar to his primary lung cancer. 
Table 1. Previously published case reports of duodenal metastasis from a primary lung carcinoma

\begin{tabular}{|c|c|c|c|c|c|c|}
\hline $\begin{array}{l}\text { Age, years/ } \\
\text { sex }\end{array}$ & Symptoms & Time of diagnosis & Location & Histopathology & Treatment & Reference \\
\hline $63 / \mathrm{M}$ & $\begin{array}{l}\text { Melena, microcytic } \\
\text { anemia }\end{array}$ & $\begin{array}{l}24 \text { months after treatment for } \\
\text { primary lung cancer }\end{array}$ & $\begin{array}{l}\text { 3rd part of } \\
\text { duodenum }\end{array}$ & $\begin{array}{l}\text { Squamous cell } \\
\text { arcinoma }\end{array}$ & Duodenectomy & 23 \\
\hline $66 / \mathrm{M}$ & Perforation & $\begin{array}{l}\text { During chemoradiation } \\
\text { for primary lung cancer }\end{array}$ & $\begin{array}{l}\text { 4th part of } \\
\text { duodenum }\end{array}$ & $\begin{array}{l}\text { Squamous cell } \\
\text { carcinoma }\end{array}$ & $\begin{array}{l}\text { Duodenectomy, followed } \\
\text { by chemotherapy }\end{array}$ & 18 \\
\hline $75 / \mathrm{M}$ & $\begin{array}{l}\text { Melena, microcytic } \\
\text { anemia, } \\
\text { intussusception }\end{array}$ & $\begin{array}{l}\text { At time of diagnosis for } \\
\text { primary lung cancer }\end{array}$ & $\begin{array}{l}\text { 2nd and 3rd parts } \\
\text { of duodenum }\end{array}$ & $\begin{array}{l}\text { Small cell } \\
\text { carcinoma }\end{array}$ & Pancreaticoduoden-ectomy & 38 \\
\hline $58 / \mathrm{M}$ & Obstruction & $\begin{array}{l}2 \text { years after treatment for } \\
\text { primary lung cancer }\end{array}$ & $\begin{array}{l}\text { 2nd part of } \\
\text { duodenum }\end{array}$ & $\begin{array}{l}\text { Large cell } \\
\text { carcinoma }\end{array}$ & $\begin{array}{l}\text { Pancreaticoduoden-ectomy } \\
\text { followed by chemotherapy }\end{array}$ & 29 \\
\hline $46 / \mathrm{F}$ & $\begin{array}{l}\text { Melena, microcytic } \\
\text { anemia }\end{array}$ & $\begin{array}{l}20 \text { days after treatment for } \\
\text { primary lung cancer }\end{array}$ & $\begin{array}{l}\text { 4th part of } \\
\text { duodenum }\end{array}$ & $\begin{array}{l}\text { Large cell } \\
\text { carcinoma }\end{array}$ & $\begin{array}{l}\text { Duodenectomy, followed by } \\
\text { chemotherapy }\end{array}$ & 30 \\
\hline $61 / \mathrm{M}$ & $\begin{array}{l}\text { Melena, weight loss, } \\
\text { hemoptysis }\end{array}$ & $\begin{array}{l}\text { At time of diagnosis for } \\
\text { primary lung cancer }\end{array}$ & $\begin{array}{l}\text { 4th part of } \\
\text { duodenum }\end{array}$ & Adenocarcinoma & $\begin{array}{l}\text { Endoscopic resection, } \\
\text { chemotherapy, blood } \\
\text { transfusion, erythropoietin }\end{array}$ & 31 \\
\hline $55 / \mathrm{M}$ & Upper GI bleeding & Unknown & $\begin{array}{l}\text { 3rd part of } \\
\text { duodenum } \\
\text { invading superior } \\
\text { mesenteric artery }\end{array}$ & Adenocarcinoma & Not specified & 32 \\
\hline $66 / \mathrm{M}$ & Upper GI bleeding & $\begin{array}{l}8 \text { months after treatment for } \\
\text { primary lung cancer }\end{array}$ & Not specified & Adenocarcinoma & Not specified & 33 \\
\hline $65 / M$ & Jaundice, obstruction & Unknown & $\begin{array}{l}\text { 2nd part of } \\
\text { duodenum }\end{array}$ & $\begin{array}{l}\text { Squamous cell } \\
\text { carcinoma }\end{array}$ & Endoscopic resection & 34 \\
\hline $54 / \mathrm{M}$ & Dysphagia & $\begin{array}{l}\text { During chemoradiation for } \\
\text { primary lung cancer }\end{array}$ & $\begin{array}{l}\text { 1st and 2nd parts } \\
\text { of duodenum }\end{array}$ & $\begin{array}{l}\text { Squamous cell } \\
\text { carcinoma }\end{array}$ & Endoscopic resection & 19 \\
\hline $69 / \mathrm{M}$ & Incidental on imaging & $\begin{array}{l}36 \text { months after treatment } \\
\text { for primary lung cancer }\end{array}$ & $\begin{array}{l}\text { 2nd part of } \\
\text { duodenum }\end{array}$ & $\begin{array}{l}\text { Small cell } \\
\text { carcinoma }\end{array}$ & $\begin{array}{l}\text { Palliative radiotherapy } \\
30 \text { Gy in } 10 \text { fractions }\end{array}$ & 35 \\
\hline $81 / \mathrm{M}$ & $\begin{array}{l}\text { Melena, shortness of breath, } \\
\text { generalized weakness, } \\
\text { symptomatic anemia }\end{array}$ & $\begin{array}{l}1 \text { month after diagnosis of } \\
\text { primary lung cancer }\end{array}$ & $\begin{array}{l}\text { 4th part of } \\
\text { duodenum }\end{array}$ & $\begin{array}{l}\text { Squamous cell } \\
\text { carcinoma }\end{array}$ & $\begin{array}{l}\text { Palliative radiation and } \\
\text { chemotherapy }\end{array}$ & 10 \\
\hline $52 / \mathrm{M}$ & $\begin{array}{l}\text { Epigastric pain, melena, } \\
\text { weight loss }\end{array}$ & $\begin{array}{l}\text { At time of diagnosis for } \\
\text { primary lung cancer }\end{array}$ & $\begin{array}{l}\text { 4th part of } \\
\text { duodenum }\end{array}$ & Adenocarcinoma & $\begin{array}{l}\text { Resection of duodenal } \\
\text { mass followed by } \\
\text { chemotherapy }\end{array}$ & 22 \\
\hline $68 / \mathrm{M}$ & Iron deficiency anemia & $\begin{array}{l}\text { At time of diagnosis for } \\
\text { primary lung cancer }\end{array}$ & $\begin{array}{l}\text { Duodenum } \\
\text { (unspecified) }\end{array}$ & Adenocarcinoma & Chemotherapy & 12 \\
\hline $71 / \mathrm{M}$ & Melena, anemia & $\begin{array}{l}\text { After one cycle of } \\
\text { chemotherapy for } \\
\text { primary lung cancer }\end{array}$ & $\begin{array}{l}\text { Duodenum } \\
\text { (unspecified) }\end{array}$ & Adenocarcinoma & Chemotherapy & 36 \\
\hline $61 / \mathrm{F}$ & $\begin{array}{l}\text { Worsening epigastric pain, } \\
\text { nausea, vomiting, reduced } \\
\text { appetite }\end{array}$ & $\begin{array}{l}\text { At time of diagnosis for } \\
\text { primary lung cancer }\end{array}$ & $\begin{array}{l}\text { Small bowel } \\
\text { (unspecified) }\end{array}$ & Adenocarcinoma & Chemotherapy & 37 \\
\hline
\end{tabular}

